ISSN 0258-7122

Bangladesh J. Agril. Res. 38(3): 491-503, September 2013

\title{
SCREENING OF DIFFERENT PLANT EXTRACTS AGAINST LEAF SPOT (Cercospora arachidicola and Cercosporidium personatum) OF GROUNDNUT (Arachis hypogaea L.)
}

\author{
M. H. HOSSAIN ${ }^{1}$ AND I. HOSSAIN ${ }^{2}$
}

\begin{abstract}
A study was undertaken to evaluate effectiveness of foliar spray with 33 plant extracts against leaf spot (Tikka) of groundnut caused by Cercospora arachidicola and Cercosporidium personatum. Bavistin and BAU-Biofungicide were included in the experiment as checks and spray of plain water represented control. Almost all treatments gave considerable reduction in disease incidence and increase in growth parameters, pod and haulm yield compared to control. The most effective materials were Bavistin $50 \mathrm{WP}$, BAU-Biofungicide, leaf extract of neem, tomato, datura black, and datura white. The materials decreased spot number per leaf, defoliation per plant, incidence of leaf spot, and number of infected leaf per plant by $35.45-60.07,42.06-72.20,51.97-63.58$, and 38.33 to $46.89 \%$ and increased pod yield and haulm yield by $64.37-111.41$ and $32.35-$ $74.71 \%$, respectively. The materials may be recommended against the disease after economic analysis.
\end{abstract}

Keywords: Groundnut, leaf spot disease, plant extract, BAU-biofungicide and Bavistin.

\section{Introduction}

Groundnut (Arachis hypogaea L.) is an important oil crop grown in many tropical and subtropical countries of the world (Wudiri and Fatoba, 1992). More than 40 fungal diseases attack the crop throughout the world (Jackson and Bell, 1969). In Bangladesh, groundnut is subjected to attack by at least 21 diseases (Talukder, 1974; Ahmed and Hossain, 1985). Among the diseases, early leaf spot caused by Cecospora arachidicola $S$. Hori and late leaf spot Cercosporidium personatum are the most important foliar diseases of the crop. Both leaf spot are commonly known as Tikka disease. The damage caused by the disease included defoliation, reduction in pod and haulm yield and quality of seeds, and increasing cost of production (Brennemen and Culbreath, 2000).

In Bangladesh, loss in yield of pod ranged from 30 to $40 \%$ in variety Dhaka1 (Hossain et al., 2005).

Various strategies have been suggested for the control of Tikka. However chemical method is still considered as the effective and economic way of

${ }^{1}$ Senior Scientific Officer, Plant Pathology, OFRD, Bangladesh Agricultural Research Institute (BARI), Comilla, ${ }^{2}$ Professor, Department of Plant Pathology, Bangladesh Agricultural University (BAU), Mymensingh, Bangladesh. 
controlling the disease (Smith and Littrell, 1980, Culbreath et al., 2002). Considering harmful impact of fungicides on environment and health use of alternative methods are necessary to find out. Biological control has been proposed as a replacement of chemical control against plant disease (Harman, 2000). Available reports suggest that the use of plant extracts with antifungal activity offers an economical, safe and easily available alternative method for the management of leaf spot disease of groundnut (Rahman and Hossain, 1996). The present study was undertaken to screen some plant extracts against leaf spot (tikka) disease of groundnut under natural epiphytotic conditions.

\section{Materials and Method}

Water extract of 23 plant materials were tested in the experiment against leaf spot of groundnut. They were extracts of neem seed (Azadirachta indicat) @ $5 \%$ $(\mathrm{w} / \mathrm{v})$, leaves of ashoka (Saroca indica). debdaru (Polyalthia longifolia), and basok ( Adhatoda vasica) and fruit of dumur (Ficus hispida) @ $10 \%$ (w/v), fresh leaves of tomato (Lycopersicon esculentum), marigold (Tagetus patula), sapota (Achras sapota), betel leaf (Piper betle), and datura (white and black), dutura flower (Datura metel) @ $20 \%$ (w/v), neem leaf (Azadirachta indica), mehedi leaf (Lawsonia internis), garlic clove (Allium sativam) and bulb of onion (Allium cepa) @ $25 \%$ (w/v), allamanda leaf (Allamanda cathartica), lemongrass (Cymbopogon citrates), ginger rhizome (Zingiber officinale), bishkatali leaf (Polygonum hydropiper), shatrodrom leaf (Blumca laceera) and arjon bark (Terminalia orjona) @ $50 \%$ (w/v) and karobi leaf (Nerium odorum) @ $100 \%$. Fresh plant materials were ground in a mortar and pestle and requisite quantity of water was added and passed through two- ply cheese cloth to prepare the extracts having appropriate concentration BAU-Biofungicide (Trichoderma based compost)@ 2.5\% and Bavision 50 WP (Carbendazim) @0.1\% were included in the experiment as check. Plain water (spray check) was used as absolute control. All the test materials were applied as foliar spray. The spray was started from 73 days after sowing and continued for 5 times at 15 days before harvest.

The experiment was carried out in the experimental field of Bangladesh Agricultural University, Mymensingh during 2007-2008. The field was prepared following standard procedures (Hossain et al., 1998). The experiment was laid out following randomized complete block design with three replications, maintaining $3.0 \mathrm{~m} \mathrm{x} 1.2 \mathrm{~m}$ unit plot, $1.5 \mathrm{~m}$ block to block and $1.0 \mathrm{~m}$ plot to plot distances. The seeds of groundnut (variety Dhaka-1) were sown on 12 December 2007 in the line about 2-3 cm depth. The seed rate was $110 \mathrm{~kg} / \mathrm{ha}$. Seed to seed and line to line distances were $10 \mathrm{~cm}$ and $40 \mathrm{~cm}$, respectively (DAE, 1985). Fertilizers were applied @ 10-50-80-30-2 kg/ha of N-P-K-S-B in the form of urea, triple super phosphate (TSP), muriate of potash (MoP), gypsum, and boric acid, respectively. Cowdung was applied @ 10 t/ha. Half of urea, the entire 
amount of other fertilizers and manure were applied to the field at the time of final land preparation. The remaining amount of urea was applied as top dress at 55 days after sowing. Irrigation, weeding and other intercultural operations were done as and when necessary.

Data on plant height, number of total, infected and defoliated leaves/plant, number of lesions per leaf and disease incidence (\% infected leaves/plant) were recorded. Incidence of leaf spot $(\%)$ was calculated following the formula stated below (Subrahmayam et al., 1995)

Disease incidence $(\%)=\frac{\text { Number of infected leaves } / \text { plant }}{\text { Total number of leaves/plant }} \times 100$

The crop was harvested after 167 days after sowing. After harvest, data on number and weight of total, mature and immature pods/plant, weight of 100pods, pod yield, and dry haulm yield were also recorded. All the data were analyzed statistically following MSTAT- C computer program.

\section{Results and Discussion}

Number of spots/leaf, defoliation of leaves/plant, and incidence of leaf spots/plant were 26.80, 42.80, and 50.80\%, respectively, under control (water spray). All treatments with the plant materials, Bavistin $50 \mathrm{WP}$ and BAUBiofungicide reduced parameters to 10.70 to 22.90 spots/leaf, 11.90-45.50 defoliated leaves/plant and 18.50-43.80 \% disease incidence/plant. The reduction under all treatments was significant over control with an exception. The exception is that extract of asoka leaf increased leaf defoliation over control, which might be due to phytotoxic effect of the materials (Table 1).

The highest reduction in spot/leaf was achieved with Bavistin $50 \mathrm{WP}$ followed by neem seed, debdaru leaf, BAU-Biofungicide and leaf extract of tomato. Their efficacy to reduce the parameter was statistically similar. The lowest reduction in this parameter was recorded when groundnut plant was sprayed with extracts of arjon bark and mehedi leaf, which were followed by neem seed and karobi leaf (Table 1).

In case of number of defoliated leaves/plant, the highest reduction was achieved with the fungicide Bavistin $50 \mathrm{WP}$ followed by that of leaf extracts of neem, black datura and BAU-Biofungicide. They gave 61.45 to72.20\% reductions over control and their effectiveness was not significantly different. Leaf extracts of tomato, marigold, sapota, shatodron, datura flower, lemongrass, black datura leaf and white datura leaf caused 40.89-46.50\% reduction in leaf, defoliation and their efficacy was statistically similar (Table 1). 
Table 1. Effect of foliar spray with twenty three plant extracts, Bavistin and BAU-biofungicide on disease incidence (\%) of tikka disease (Cercospora arachidicola and Cercosporidium personatum) of groundnut.

\begin{tabular}{|c|c|c|c|c|c|c|c|c|}
\hline \multirow{2}{*}{$\begin{array}{c}\text { Botanicals/ } \\
\text { BAU-biofungicide with } \\
\text { dose }\end{array}$} & \multicolumn{2}{|c|}{ Spot number/leaf } & \multicolumn{2}{|c|}{ Defoliated leaves/plant } & \multicolumn{2}{|c|}{ Incidence of leaf spot/ plant } & \multirow{2}{*}{$\begin{array}{c}\text { Infested leaf } \\
\text { number } \\
\text { / plant }\end{array}$} & \multirow{2}{*}{$\begin{array}{c}\% \\
\text { infected } \\
\text { leaves/ } \\
\text { plant }\end{array}$} \\
\hline & Number & $\%$ reduction $^{1}$ & Number & $\%$ reduction $^{1}$ & Number & $\%$ reduction $^{1}$ & & \\
\hline Tomato leaf (20\%) & 15 & 44.03 & 22.9 & 46.5 & 22.2 & 56.3 & 29.3 & 43 \\
\hline Marigold leaf (2.5\%) & 17.5 & 34.7 & 23.2 & 45.79 & 28.6 & 43.7 & 32.8 & 36.19 \\
\hline Sapota leaf $(20 \%)$ & 19 & 29.1 & 25.3 & 40.89 & 33.8 & 33.46 & 41.3 & 19.65 \\
\hline Betel leaf (20\%) & 20 & 25.37 & 36.3 & 15.19 & 35.2 & 30.71 & 43.7 & 14.98 \\
\hline Allamanda leaf (33\%) & 19.5 & 27.24 & 35.1 & 17.99 & 43.3 & 14.76 & 45.9 & 10.7 \\
\hline Karobi leaf (50\%) & 21.7 & 19.03 & 39.9 & 6.78 & 32.5 & 36.02 & 38.2 & 25.68 \\
\hline Neem leaf $(20 \%)$ & 13.7 & 48.88 & 14.8 & 65.42 & 20.7 & 59.25 & 30.6 & 40.47 \\
\hline Neem seed $(5 \%)$ & 22.7 & 15.3 & 36.9 & 13.79 & 35.6 & 29.92 & 37.6 & 26.85 \\
\hline Garlic clove (20\%) & 20.3 & 24.25 & 26.3 & 38.55 & 32 & 37.01 & 38.7 & 24.71 \\
\hline Biskathali leaf (33\%) & 16.2 & 39.93 & 26.4 & 38.32 & 33 & 35.04 & 37.5 & 27.04 \\
\hline
\end{tabular}


Table 1. Cont'd

\begin{tabular}{|c|c|c|c|c|c|c|c|c|}
\hline Shatodron leaf (33\%) & 18.1 & 32.46 & 23.5 & 45.09 & 39.2 & 22.83 & 40.7 & 20.82 \\
\hline Lemongrass (33\%) & 15.4 & 42.54 & 24.3 & 43.22 & 29.6 & 41.73 & 35.1 & 31.71 \\
\hline Onion bulb (20\%) & 19.3 & 27.99 & 26.5 & 38.08 & 27.6 & 45.67 & 33.7 & 34.44 \\
\hline Debdaru leaf (10\%) & 14.9 & 44.4 & 23.3 & 45.56 & 22.5 & 55.71 & 28.8 & 43.97 \\
\hline Darura leaf (white) (20\%) & 17.3 & 35.48 & 24.8 & 42.06 & 24.4 & 51.97 & 31.7 & 38.33 \\
\hline BAU-biofungicide (2.5\%) & 15 & 44.03 & 16.5 & 61.45 & 22.3 & 56.1 & 29.3 & 43 \\
\hline Bavistin (0.1\%) (check) & 10.7 & 60.07 & 11.9 & 72.2 & 18.5 & 63.58 & 27.3 & 46.89 \\
\hline Control (plain water) & 263.8 & - & 42.8 & - & 50.8 & - & 51.4 & - \\
\hline
\end{tabular}

${ }^{1}$ percentage of reduction over control 
The incidence of the disease was reduced by 13.78-63.58\% over control. The highest reduction was recorded from the treatment Bavistin $50 \mathrm{WP}$, which was statistically similar to the extract of black datura leaf, neem leaf, tomato leaf, BAU-Biofungicide, debdaru leaf, white datura leaf, and datura flower. The least effective materials were dumur fruit followed by allanmanda leaf and arjon bark (Table 1).

The highest number of infected leaves/plant was 51.40 under control and the treatment with arjon bark. Except extract of asoka leaf and dumur fruit, extracts of other plant materials, Bavistin $50 \mathrm{WP}$ and BAU-Biofungicide gave significant reduction in the parameter with in the range of $27.30-40.70 \%$ per plant. The effective materials caused 10.70-46.89\% reduction of the parameter over control.

Results of the present study revealed that severity of the tikka disease of groundnut was reduced effectively by different treatments with plant extracts Bavistin $50 \mathrm{WP}$ and the BAU-Biofungicide. On an average, the most effective plant material was black datura leaf, followed by the leaf extract of neem, tomato, debdaru, white datura, and datura flower. The findings are in agreement with the findings of Aage et al. (2003). Similar results have also been reported by Natarajan et al. (2005), Kishore and Pande (2005) and Abdulrahman and Alkhali (2005).

Plant height and total number of leaves/plant under control were $44.4 \mathrm{~cm}$ and 101.2, respectively. All the treatments with 23 plant extracts, Bavistin $50 \mathrm{WP}$ and BAU-Biofungicide increased the parameters to $47.80-67.50 \mathrm{~cm}$ and $104.00-$ 147.60 , respectively. In the case of plant height, the increase was significant under all treatments compared to control except garlic clove @ $20 \%$ and neem seed $(5 \%$.) Maximum plant height was recorded from the treatment with Bavistin $50 \mathrm{WP}$, which was statistically similar to BAU-Biofungicide, leaf extract of tomato, neem, marigold, sapota, debdaru, and datura flower. The increase in total number of leaves/plant due to application of allamanda leaf, datura fruit, neem leaf and shatodron leaf over control was not significant. Other treatments gave significant increase in the parameter over control (Table 2).

Effect of basok leaf, dumur fruit, and garlic $(50 \%)$ on pod yield/plant was not considerable compared to control. Other treatments caused increase in total pod number and pod weight and healthy pod number per plant to 22.00-32.70, 19.50-29.80 and 15.40-24.40 g, respectively. The increase was significant compared to control. Maximum increase in total as well as healthy pod number was obtained with Bavistin $50 \mathrm{WP}(0.1 \%)$, which was not significantly different from BAU-Biofungicide, leaf extract of tomato, neem, datura black, debdaru, onion bulb and datura leaf white. Both total and healthy pod weight was also achieved with Bavistin followed by leaf extract of tomato, datura black, neem, 
Table 2. Effect of foliar spray with twenty three plant extract, Bavistin 50WP and BAU-biofungicide applied against tikka disease (Cercospora arachidicola and Cercosporidium personatum) of groundnut on plant growth of the crop.

\begin{tabular}{|c|c|c|c|c|c|c|}
\hline \multirow{2}{*}{$\begin{array}{l}\text { Botanicals/BAU- } \\
\text { biofungicide with dose }\end{array}$} & \multirow{2}{*}{$\begin{array}{l}\text { Plant } \\
\text { height } \\
(\mathrm{cm})\end{array}$} & \multirow{2}{*}{$\begin{array}{l}\text { Leaf number/ } \\
\text { plant }\end{array}$} & \multirow{2}{*}{$\begin{array}{l}\text { Pods number/ } \\
\text { plant }\end{array}$} & \multirow{2}{*}{$\begin{array}{l}\text { Healthy pods/ } \\
\text { plant }\end{array}$} & $\begin{array}{l}\text { Pods wt/ } \\
\text { plant }\end{array}$ & \multirow{2}{*}{$\begin{array}{c}\text { Healthy pods wt/ } \\
\text { plant } \\
(\mathrm{g}) \\
\end{array}$} \\
\hline & & & & & (g) & \\
\hline Tomato leaf (20\%) & 64.8 & 132.1 & 3030 & 27.8 & 21.9 & 21.2 \\
\hline Marigold leaf (2.5\%) & 62.7 & 114.7 & 25.2 & 22.7 & 19.5 & 18.4 \\
\hline Asoka leaf (10\%) & 63.3 & 120.3 & 24.2 & 22.3 & 18 & 17.4 \\
\hline Arjon bark (50\%) & 63.3 & 122.1 & 23.4 & 20.1 & 16.4 & 15.8 \\
\hline Sapota leaf (20\%) & 62 & 122.1 & 25.6 & 23.2 & 19.6 & 18.4 \\
\hline Betel leaf (20\%) & 57.7 & 124 & 25.6 & 23.2 & 17.5 & 16.4 \\
\hline Allamanda leaf (1:2) & 60.9 & 106 & 26 & 22.1 & 17.4 & 16.2 \\
\hline Ginger clove (50\%) & 60.5 & 109.5 & 16 & 13.2 & 10.2 & 9.7 \\
\hline Dumur fruit (10\%) & 63.7 & 109.1 & 18.5 & 15.8 & 12 & 11.4 \\
\hline Basok leaf $10 \%$ ) & 62.7 & 110 & 18.4 & 16.6 & 15.2 & 14.8 \\
\hline Karobi leaf $(50 \%)$ & 54.9 & 117.4 & 22.3 & 19.5 & 15.7 & 15.1 \\
\hline Neem leaf $(20 \%)$ & 58.7 & 147.6 & 29.6 & 27.6 & 20.6 & 20 \\
\hline Neem seed (5\%) & 49.6 & 105.7 & 22.9 & 20.8 & 16.3 & 15 \\
\hline Garlic clove (20\%) & 47.8 & 120.9 & 22.1 & 19.5 & 17.8 & 17.1 \\
\hline Biskathali leaf (33\%) & 56.7 & 113.8 & 22.7 & 19.6 & 15.4 & 15.6 \\
\hline
\end{tabular}




\section{Table 2. Cont'd}

\begin{tabular}{|c|c|c|c|c|c|c|}
\hline Shatodron leaf (33\%) & 56 & 104 & 25.3 & 21.4 & 18.5 & 17.8 \\
\hline Lemongrass (33\%) & 60.3 & 118.3 & 27.7 & 24.9 & 19.1 & 16.8 \\
\hline Onion bulb (20\%) & 62.7 & 122.4 & 28.9 & 26 & 18.1 & 18.1 \\
\hline Debdaru leaf $(10 \%)$ & 66.6 & 127.8 & 29.1 & 26.4 & 19.2 & 18.8 \\
\hline Darura leaf (white) (20\%) & 60.8 & 130 & 28 & 25.6 & 19.6 & 19 \\
\hline BAU-biofungicide $(2.5 \%)$ & 66.1 & 132.1 & 29.8 & 29.8 & 19.5 & 18.6 \\
\hline Bavistin $(0.1 \%)$ (check) & 67.5 & 129 & 32.7 & 29.7 & 24.4 & 23.5 \\
\hline Control (plain water) & 44.4 & 101.2 & 17.7 & 13.5 & 11.5 & 11.4 \\
\hline
\end{tabular}


Table 3. Effect of 23 plant extracts, Bavistin 50WP and BAU-biofungicide applied against tikka disease (Cercospora arachidicola and Cercosporidium personatum) on pod and haulm yield of the crop.

\begin{tabular}{|c|c|c|c|c|c|}
\hline \multirow{2}{*}{$\begin{array}{l}\text { Botanicals/BAU-biofungicide } \\
\text { with dose }\end{array}$} & \multirow{2}{*}{ 100- pod wt (g) } & \multirow{2}{*}{ Pod yield (kg/ha) } & \multirow{2}{*}{$\begin{array}{l}\text { Yield of dry } \\
\text { haulms (t/ha) }\end{array}$} & \multicolumn{2}{|c|}{ Increase over control $(\%)^{1}$} \\
\hline & & & & Pod yield & Haulm yield \\
\hline Tomato leaf (20\%) & 87.7 & 1981 & 5.3 & 71.81 & 55.59 \\
\hline Marigold leaf (2.5\%) & 85.9 & 1953 & 4.5 & 69.41 & 31.47 \\
\hline Asoka leaf $(10 \%)$ & 86.6 & 1799 & 4.3 & 56.06 & 25.88 \\
\hline Arjon bark (50\%) & 85.1 & 1636 & 4.2 & 41.91 & 22.06 \\
\hline Sapota leaf (20\%) & 85.4 & 1959 & 4.9 & 69.9 & 43.24 \\
\hline Betel leaf (20\%) & 83.8 & 1750 & 4.1 & 51.79 & 19.12 \\
\hline Allamanda leaf (1:2) & 81.4 & 1736 & 4.8 & 50.57 & 41.18 \\
\hline Ginger clove (50\%) & 83.5 & 1038 & 3.8 & -1.28 & 10.29 \\
\hline Dumur fruit (10\%) & 80.4 & 1200 & 4.1 & 4.11 & 20.59 \\
\hline Basok leaf 10\%) & 78.7 & 1339 & 4.8 & 16.09 & 40 \\
\hline Karobi leaf (50\%) & 86.9 & 1571 & 4.4 & 36.29 & 30 \\
\hline Neem leaf $(20 \%)$ & 87.9 & 2131 & 4.9 & 84.85 & 43.53 \\
\hline Neem seed $(5 \%)$ & 80.5 & 1633 & 4.1 & 41.65 & 21.47 \\
\hline Garlic clove (20\%) & 79.8 & 1843 & 4.6 & 59.85 & 34.71 \\
\hline Biskathali leaf (33\%) & 86.7 & 1603 & 3.7 & 39.05 & 9.71 \\
\hline Shatodron leaf (33\%) & 80.6 & 1852 & 4.1 & 59.85 & 20.59 \\
\hline
\end{tabular}




\begin{tabular}{lllccc} 
Table 3. Cont'd & \multicolumn{1}{c}{. } \\
\hline Datura flower (10\%) & 87.6 & 1973 & 4.6 & 71.09 & 34.41 \\
Lemongrass (33\%) & 85.8 & 1774 & 4.3 & 53.9 & 27.06 \\
Onion bulb (20\%) & 86.4 & 1954 & 4.7 & 69.45 & 37.35 \\
Debdaru leaf (10\%) & 87.8 & 1922 & 5 & 66.69 & 47.94 \\
Mehadi leaf (25\%) & 80.7 & 1610 & 4.5 & 39.61 & 31.47 \\
Datura leaf (black) (20\%) & 88.3 & 1916 & 5.3 & 66.22 & 55.88 \\
Darura leaf (white) (20\%) & 86.1 & 1895 & 4.5 & 64.37 & 32.35 \\
BAU-biofungicide (2.5\%) & 88.9 & 2191 & 5.5 & 90.03 & 61.76 \\
Bavistin (0.1\%) (check) & 89.2 & 2438 & 5.6 & 111.41 & 65.29 \\
Control (plain water) & 76.7 & 1153 & 3.4 & - & - \\
\multicolumn{1}{c}{ LSD(P $\geq 0.001)$} & 5.72 & 383.3 & 0.68 & - & - \\
\hline
\end{tabular}

${ }^{1}$ percentage of increase over control 
datura white and datura flower. Leaf extracts of tomato, datura black, and neem showed more or less similar results and their effect with Bavistin (Table 3). Similar observation made by Subrahmanyam et al. (1984), Gwary and Asala (2006).

Except allamanda leaf, basok leaf, dumur fruit, garlic clove, mehedi leaf, neem seed, and shatodron leaf, other treatments caused significant increase in 100 pod weights compared to control. The increase ranged from 83.50 to 89.20 $\%$. The highest 100-pod weight was obtained with Bavistin, which was statistically similar to BAU-Biofungicide and extract of neem leaf, but significantly higher compared to other effective plant materials.

Pod yield under control was $1039 \mathrm{~kg} / \mathrm{ha}$ and that under basok leaf, dumur fruit, and ginger clove was 1339,1200 and $1038 \mathrm{~kg} / \mathrm{ha}$, respectively. Their differences were not significant. Pod yield under other treatments ranged 1571$2438 \mathrm{~kg} / \mathrm{ha}$. The increase was 36.29 to $111.41 \%$ and significantly higher over control. Maximum yield was produced by Bavistin $50 \mathrm{WP}$, which was statistically similar to leaf extract of neem and tomato.

Dry haulm yield under control, ginger and biskatali was 3.4, 3.7 and $3.8 \mathrm{t} / \mathrm{ha}$, respectively. Their differences were not significant. Treatments with other plant extracts, BAU-Biofungicide and Bavistin 50 WP increased haulm yield to 4.10 to $5.60 \mathrm{t} / \mathrm{ha}$. The increase was $20.59-64.71 \%$ and significantly higher to control. The highest haulm yield was obtained with Bavistin, which was statistically similar to BAU-Biofungicide, leaf extract of datura black, debdaru and tomato (Table 3).

Results of the present study reveal that except few different plant materials tested, BAU-Biofungicide and Bavistin 50 WP are effective to control Tikka disease and to increase pod as well as haulm yield of groundnut. Efficacy of most of the extracts is satisfactory and as per with BAU-Biofungicide and Bavistin. The results support the findings of Adiver (2004), Gopal et al., (2006) and Ihejirika et al. (2006).

Nine plants extract viz., neem leaf, tomato leaf, datura leaf (black), datura flower, onion bulb, debdaru leaf, and datura leaf white and BAU-Biofungicide may be selected to use against tikka disease. However, before recommendation economic analysis is needed and principles of their efficacy need to be determined.

\section{References}

Aage, V. E., S. J. Gaikwad, G. T. Behere and V. S. Tajame. 2003. Efficacy of extracts of certain indigenous medicinal plant against Cercospora leaf spot of groundnut. $J$. Soils and Crops 13 (1): 140-144. 
Abdulrahman, A. and Alkhaili, Aba. 2005. Antifungal activity of some extracts against some plant pathogenic fungi. Pakistan J. Biol. Sci. 8 (3): 413-417.

Adivar, S. S. 2004. Field efficacy of botanical preparations on late leaf spot $(C$. Personata) of groundnut (Arachis hypogaea). Oil Seed Res. 21 (2): 369-370.

Ahmed, H .U. and M. M. Hossain. 1985. Crop disease survey and establishment of a herbarium at BARI. Final Report, Plant Pathol. Div., BARI. Joydebpur, Gazipur. P. 107.

Brenneman, T. B. and A. K. Culbreath. 2000. Peanut disease control. Pp. 96-97. In: "200 Ga. Pest control Handbook” (P. Guille beau, ed.). Univ. Ga. Coop. Ext. Serv. Special Bull. p 28 and 20

Culbreath, A. K., K. L. Stevenson and T. B. Brenneman. 2002. Management of late leaf spot of peanut with benonyl and chlorothalonil: A study in preserving fungicide utility. Plant Dis. 56: 349-355.

DAE, 1985. A Guide Book on Production of oil crops in Bangladesh. $1^{\text {st }}$ Ed. Pioneer Printing Press Ltd., Dhaka. P. 40.

Gopal, K., S. K. Ahamed and G. P. Babu. 2006. Estimation of losses due to tikka leaf spot in groundnut (Arachis hypogaea L.). Legume-Res. 29 (4): 289-291.

Gwary, D. M. and S.W. Asala. 2006. Cost-benefit of fungicidal control of anthracnose on sorghum in northern Nigeria. Int. J. Agri. Biol. 8 (3): 306-308.

Harman, G. E. 2000. Myths and dogma of bio-control, change in perceptions derived from research on Trichoderma harzianum T-22. Plant Dis. 87: 377-393.

Hossain, M. S., K. M. Khalequzzaman, M. A. Hossain, M. Hossain, and M. R. A. Mollah. 2005. Screening of groundnut genotypes for leaf spots and rust resistance. $J$. Subtropical Agril. Res. and Develop. 3(1): 57-60.

Hossain, M. H., M. S Nahar, M. I. Haq, M. A Haque and K. U. Ahammad. 1998. Effect of fungicides and spacing on severity of Tikka and Rust diseases of groundnut. Bangladesh J. Agril. Res. 23(3): 463-468

Ihejirika, G. O., M. I. Nwufo, Duruigbo, C. I. Onwerenadii, O. P. Obili, E. R. Omuoha K. O. Ogbede. 2006. Effect of plant extracts and plant density on the severity of leaf spot disease of groundnut. J. Plant Sci. 1 (4):374-377.

Jackson, C. R. and D. K. Bell. 1969. Diseases of peanut (groundnut) caused by fungi rust Puccinia arachidis Speg. Research Bulletin no. 56. Georgia Agricultural Experiment Station, Athens, Georgia, USA., Pp. 47-51.

Kishore, G. K and S. Pande. 2005. Integrated applications of aqueous leaf extract of Datura metel and chlorothalonil improved control of late leaf spot and rust of groundnut. Australasian Plant Pathol. 34 (2): 261-264.

Natarajan, D., K. Srinivasan, C. Mohanasundari, G. Perumal, M. A. N. Dheen, G. A Ganapathi and T. Rajarajan. 2005. Antifungal properties of three medicinal plant extracts against Cercospora arachidicola. Advances in Plant Sciences 18 (1): 45-47.

Rahman, M. A. and I. Hossain. 1996. Controlling Cercospora leaf spot of Okra with plant extracts. Bangladesh Hort. 24 (1\&20): 147-149. 
Smith, D. H. and R. H. Littrell. 1980. Management of peanut foliar diseases with fungicides. Plant Dis. 66: 574-575.

Subrahmanyam, P., J. H. Williams, D. Mcdonald and R. W. Gibbons. 1984. The influence of foliar diseases and their control by selective fungicides on a range of groundnut (Arachis hypogaea L.) genotypes. Ann. Appl. Biol. 104: 467-476.

Subrahmanyam, P., D. McDouald, F. Walliyar, L. J. Raddy and P. V. Subba Rao. 1995. Screening methods and sources of resistance to rust and late leaf spot of groundnut. Information Bull. 47. ICRISAT. Patencheru, India. 20p.

Talukder, M. J. 1974. Plant diseases of Bangladesh. Bangladesh J. Agric. Res. 1: 61-86.

Wudiri, B. B. and I. O.Fatoba. 1992. Cereals in the food economy of Nigeria. In Proc. of workshop on Recent Dev. In Cereal Prod. in Nigeria Kaduna 2-4 Sept. 1991. Organised by IITA, Ibadan, Nigeria. Pp: 13-32. 